STUDIA POLONIJNE

T. 40. LUBLIN 2019

DOI: http://dx.doi.org/10.18290/sp.2019.8

DANIEL KIPER

\title{
WPLYW POLSKIEJ EMIGRACJI W EUROPIE ZACHODNIEJ NA ŻYCIE POLITYCZNE POLONII AMERYKAŃSKIEJ PRZELOMU LAT SIEDEMDZIESIĄTYCH I OSIEMDZIESIĄTYCH XIX WIEKU
}

Projekty powołania do życia polskiej ogólnonarodowej organizacji w Stanach Zjednoczonych dojrzewały w momencie, gdy w Europie Zachodniej nie było liczących się środowisk, które miałyby realną możliwość zorganizowania centralnego ośrodka władzy na emigracji. Postyczniowi wychodźcy polityczni, rozsiani po całym świecie dążyli do podtrzymania tradycji emigracji lat 30. i 40. XIX wieku, wyznaczającej drogowskazy wszelkim nurtom ideowo-politycznym. Nowa rzeczywistość, w której przyszło działać uczestnikom powstania na Zachodzie Europy, nie sprzyjała rozwijaniu działalności rewolucyjnej. Inicjatywy podejmowane przez politycznych wychodźców w latach 60. i 70. XIX wieku nie doprowadziły do powstania organizacji zdolnej zespolić siły do wspólnych działań na polu walki o niepodległość. Emigracja polska weszła w okres ideowych oraz instytucjonalnych przeobrażeń1. Poważnemu osłabieniu uległy również jej kontakty z krajem, a także rządami i społeczeństwami krajów zachodnich (Francji, Anglii, Belgii, Włoch), które wcześniej stanowiły dla niej oparcie². Największym problemem okazał się brak zaufania społeczeństwa w kraju do politycznych instytucji wychodźczych ${ }^{3}$. Opozycja kraj-emigracja nigdy nie była tak wyraźna jak po powstaniu styczniowym, gdy na ziemiach polskich zatryumfowała filozofia pozytywistyczna, a wpływowe

Dr DANIEl KiPer - asystent naukowy, Ośrodek Archiwów, Bibliotek i Muzeów Kościelnych, Katolicki Uniwersytet Lubelski Jana Pawła II; e-mail: bugaj3@wp.pl

${ }^{1}$ Korespondencje Gaz[ety] N.Y., „Gazeta Nowojorska” 11 VII 1874, s. 2-3; S. TARnOwsKI, Upadek emigracji, „Gazeta Polska” (Czerniowce) 14 XII 1890, s. 1-2. Por. J. NowaK, Od narodu historycznego do wspólnoty etnicznej. Przemiany w polskiej refleksji nad narodem po 1864 roku, „Teksty Drugie" 6(2014), s. 369-390.

2 E. Kozlowski, Generat Józef Hauke-Bosak 1834-1871, Warszawa 1973, s. 206-207; Historie Polski w XIX wieku, red. A. Nowak, t. IV, Warszawa 2015, s. 188-193.

${ }^{3}$ Emigracja polska, „Głos Wolny” 31 VII 1864, s. 189; [Bez tyt.], „Dziennik Poznański” 12 XI 1865, s. 1-2; BolesŁawita [J.I. Kraszewski], Z roku 1868. Rachunki, Poznań 1869, s. 683-684; L.A. CioŁkoszowie, Zarys dziejów socjalizmu polskiego, t. II, Londyn 1972, s. 279. 
środowiska dziennikarskie kształtujące opinię publiczną potępiały nosicieli idei powstańczych jako radykałów ${ }^{4}$. Wymownym przykładem nastrojów lojalistycznych był zupełny brak zainteresowania polskojęzyczną prasą wydawaną poza granicami trzech zaborów5 . Popularność idei pozytywistycznych na ziemiach polskich nie wiązała się wyłącznie z reakcją na klęskę powstania, ale wynikała także z oddziaływania na inteligencję polską prądów ideowych dominujących w ówczesnej Europie ${ }^{6}$.

Wydarzenia roku 1870 symbolicznie zamknęły epokę irredenty, oddalając szanse na realizację projektów niepodległościowych. Szczególne znaczenie dla zmieniającego się układu sił geopolitycznych w Europie miały konsekwencje wojny prusko-francuskiej. Osłabiony potencjał polityczny Francji, z którą od początku wiązano nadzieję na wyzwolenie, negatywnie wpłynął na morale polskiego wychodźstwa. Z kolei wydarzenia związane z Komuną Paryską, w trakcie której śmierć poniosło wielu Polaków, skutkowało nie tylko bezpowrotnymi stratami osobowymi najbardziej ideowych jednostek, ale również antypolskim nastawieniem francuskiej opinii publicznej ${ }^{7}$. Nieco lepiej wiodło się nad Sekwaną tylko środowiskom konserwatywnym, skupionym wokół obozu Hotelu Lambert, oraz niewielkim organizacjom charytatywno-oświatowym działającym pod jego auspicjami ${ }^{8}$. Im bardziej sytuacja polityczna w Europie stawała się stabilna, tym bardziej słabł potencjał mobilizacyjny polskiej emigracji, szczególnie stronnictw odwołujących się do tradycji insurekcyjnych, wpisujących swoją politykę w międzynarodowe ruchy wolnościowe. Gwarancje utrzymania status quo na niekorzyść tzw. sprawy polskiej dawał sojusz Francji z Rosją, który został oficjalnie przypieczętowany w 1893 r. ${ }^{9}$ Wymiernych korzyści nie uzyskano również od innych liczących się po-

${ }^{4}$ „Obserwując zajadłość polemicznych wypadów antyemigracyjnych - pisała Alina Witkowska - można by sądzić, że gdyby emigracja nie istniała, należałoby ją stworzyć dla lepszego samopoczucia społeczności krajowej” (A. Wiткоwska, Wielkie stulecie Polaków, Warszawa 1987, s. 171).

5 Biblioteka Jagiellońska [dalej: BJ], sygn. Rkps 6537, Józef I. Kraszewski do Józefa Tokarzewicza 11 V 1869 r., k. 285-286.

${ }^{6}$ M. Biddiss, Progress, prosperity, and positivism: cultural trends in mid-century, [w:] Themes in modern European history 1830-1890, ed. B. Waller, London-New York 1990, s. 200-203; M. MICIŃsKA, Inteligencja na rozdrożach 1864-1918, Warszawa 2008, s. 161-176.

${ }^{7}$ H. Korwin-Milewski, Siedemdziesiąt lat wspomnień (1855-1925), Poznań 1930, s. 97; por. K. Dunin-WąSOwicz, Francuska opinia publiczna wobec sprawy polskiej i Polaków w latach 1885 1984, Wrocław 1987.

8 J. ZDRADA, Zmierzch Czartoryskich, Warszawa 1969; J. BoREJSZA, Emigracja polska po powstaniu styczniowym, Warszawa 1966, s. 50-60.

${ }^{9}$ M. Sobolewski, Od drugiego Cesarstwa do Piątej Republiki. Z dziejów politycznych Francji 1870-1958, Warszawa 1963, s. 122-123. Reakcje na sojusz Francji z Rosją prasy polskiej krajowej i emigracyjnej zob. D. FILAR, Wptyw sojuszu rosyjsko-francuskiego 1893/1894 r. na program polityczny Ligi Polskiej i Ligi Narodowej, „Zeszyty Historyczne” 3(1963), s. 123-154. 
tęg europejskich, takich jak Anglia, chociaż pod koniec lat 70. pojawiła się nadzieja na kolejne antyrosyjskie powstanie w Królestwie przy pomocy tego państwa ${ }^{10}$. Jedynym miejscem w Europie, gdzie istniało realne podłoże do wojen i rewolucji, był Półwysep Bałkański, który w miarę postępującego upadku Turcji stawał się terenem rywalizacji Rosji i Austro-Węgier.

Naturalną konsekwencją słabego oddziaływania politycznego polskiej emigracji we Francji było zahamowanie rozwoju polskich instytucji i stowarzyszeń o charakterze oświatowym i kulturalnym ${ }^{11}$. Niewielkie enklawy narodowe w Szwajcarii, Anglii, Turcji czy Rumunii nie miały większego wpływu na geopolityczne uwarunkowania w ówczesnej Europie. Wielu emigrantów wracało do kraju korzystając z dogodnych warunków politycznych, jakie panowały w Galicji. W gwałtownie zmieniającym się świecie, do końca XIX wieku emigracja polska nie była w stanie znaleźć nowych form aktywności i filozofii działania wobec nieznanych wcześniej zjawisk kulturowo-społecznych, by móc zaistnieć ponownie na scenie politycznej jako partner w rozgrywkach dyplomatycznych.

Marazm i skłócenie organizacji niepodległościowych zbiegły się z fermentem coraz liczniejszej grupy zwolenników socjalizmu zgrupowanych w Szwajcarii oraz Francji ${ }^{12}$. Powołali oni w 1882 r. pierwszą socjalistyczną organizację wśród emigracji polskiej o nazwie Stowarzyszenie Wzajemnej Pomocy Robotników w Paryżu ${ }^{13}$. Dziesięć lat później nad Sekwaną powstał Związek Zagranicznych Socjalistów Polskich ${ }^{14}$. Zalążki ruchu socjalistycznego zaczęły kiełkować w momencie, gdy grupy społeczne będące dotychczas przedmiotem polityki, zaczęły odgrywać zasadniczą rolę w rozgrywkach politycznych. Dlatego też każdy typ publicznych czy tajnych inicjatyw niepodległościowych musiał uwzględnić uczestnictwo w tych przedsięwzięciach szerszych niż dotychczas mas ludzkich. Skład społeczny polskiej emigracji (głównie na terenach Francji i Niemiec) zmienił się zasadniczo po napływie fal wychodźców zarobkowych ${ }^{15}$. W tej konfiguracji

${ }^{10}$ Historia dyplomacji polskiej, 1795-1918, t. III, red. L. Bazylow [i in.], Warszawa 1982, s. 718719; H. WereszycKi, Koniec sojuszu trzech cesarzy, Warszawa 2010, s. 297-298.

11 Zob. W. ŚladKowsKi, Emigracja polska we Francji 1871-1918, Lublin 1980, s. 57-67; Z.F.M. [Z. Miłkowski], Z wychodźstwa polskiego w Europie, „Przegląd Wszechpolski” 1 IV 1896, s. $149-151$.

${ }^{12}$ N.M. Naimark, The History of the „Proletariat”. The Emergence of Marxism in the Kingdom of Poland, 1870-1887, Boulder 1979, s. 93-99.

13 W. ŚLAdKowsKi, Emigracja polska, s. 75.

${ }_{14}$ Cz. KozŁowski, Zarys dziejów polskiego ruchu robotniczego do 1948 roku, Warszawa 1980, s. $110-113$.

${ }^{15}$ K. MurzynowsKa, Polska emigracja europejska w latach 1870-1923, [w:] Stan i potrzeby badań nad zbiorowościami polonijnymi, Wrocław 1976, s. 330-343. 
kolonie polskie w Stanach Zjednoczonych stały się jednym z nielicznych miejsc, gdzie potencjalnie istniała możliwość swobodnego rozwijania życia narodowego. O tym, że stopień zaangażowania w sprawy publiczne mieszkających tam Polaków stał się widoczny, świadczy choćby zainteresowanie Polonią amerykańską niemieckiej policji ${ }^{16}$.

Wpływowe, choć nieliczne skupisko emigracyjne utworzyło się w Rapperswilu przy Muzeum Polskim ${ }^{17}$. W ośrodku tym podejmowano próby skupienia rozproszonych środowisk polskich nie tylko w Europie, ale coraz bardziej dostrzegano potencjał polityczno-demograficzny, a potem ekonomiczny diaspory polskiej za oceanem $^{18}$. Nasilenie kontaktów z przedstawicielami polsko-amerykańskich wspólnot nastąpiło w czasie wojny rosyjsko-tureckiej $(1877-1878)^{19}$. W kolejnych latach wciągano w orbitę zainteresowań tych Polaków z Nowego Świata, którzy posiadali zdolności przywódcze i deklarowali przywiązanie do polskości ${ }^{20}$. Wiele kontaktów pozyskał założyciel Muzeum Władysław Plater, który m.in. dzięki osobistym znajomościom z konsulem Stanów Zjednoczonych w Szwajcarii napisał w imieniu Zarządu Muzeum oficjalny list do prezydenta Ulyssesa Granta z okazji setnej rocznicy ogłoszenia niepodległości przez Stany Zjednoczone ${ }^{21}$. Pretekstem do nawiązywania dobrych relacji z ośrodkiem polskim w Szwajcarii były również rozmaite wydarzenia na arenie międzynarodowej, jak choćby jubileusze wybitnych działaczy niepod-

${ }^{16}$ Z. KLejn, Policja pruska wobec Polonii amerykańskiej, „Problemy Polonii Zagranicznej” 3(1963), s. 153-168.

17 B. Mansfeld, Rapperswil Wtadystawa Platera, „Więź” 1972, nr 11, s. 130-136; A. Buchman, Muzeum Polskie w Rapperswilu - dzieło emigracji postyczniowej, [w:] Emigracja postyczniowa 1863 roku, red. E. Niebelski, Lublin 2010, s. 195-204.

${ }_{18}$ Szerzej o towarzystwie z St. Gallen zob. Adres Polaków San Francisco, „Gazeta Nowojorska” 13 VI 1874, s. 4; Odpowiedź Zarządu Muzeum Narodowego do Towarzystwa Polaków w Kalifornii, „Gazeta Nowojorska” 20 VI 1874, s. 4.

19 K. GroniowsKi, Rapperswil jako ośrodek polityczny (1868-1887), „Annales UMCS”, Sectio F. Humaniora 1982, t. 37, s. 399

${ }^{20}$ Biblioteka Polska w Paryżu [dalej: BPwP], sygn. akc. Rkps 2692, Władysław Plater do Henryka Bukowskiego, Villa Broelberg 28 VIII 1879, [brak pag.]; W. Plater, Do Szanownego Towarzystwa Narodowego Kościuszki w Chicago, Villa Broelberg, 4 V 1877, „Gazeta Polska w Chicago” 31 V 1877, s. 2; S. Osada, Historia Zwiazku Narodowego Polskiego, t. I, Chicago 1905, s. 71; K. GroNIOwski, Poczatki organizacji polonijnych w Stanach Zjednoczonych, „Kwartalnik Historyczny” 88(1981), nr 3, s. 680-681; Roczne Zdanie Sprawy Zarzadu Muzeum Narodowego w Rapperswilu z dn. 29 XI 1879, Zurych 1879, s. 4; Korespondencja z Szwajcarii do Komitetu Zwiazku Polskiego w Filadelfii, „Przyjaciel Ludu” 16 VI 1880, s. 3; Biblioteka Narodowa [dalej: BN], sygn. Rkps 10117, Stanisław Artwiński do Władysława Platera, 20 XII 1879, Nowy Jork, k.1; tamże, Sygurd Wiśniowski do Władysława Platera, Nowy Jork, 27 VIII 1880, k. 299v.

${ }^{21}$ S. OsadA, Historia, s. 73-74; W. KŁYsZewsKi, Z moich wspomnień, Kraków 1961, s. 59. Por. [Bez tyt.] „Głos Wolny” 10 VI 1865, s. 286. 
ległościowych czy rocznice powstań narodowych ${ }^{22}$. Jednym z nich były obchody pięćdziesięcioletniej pracy literackiej Józefa Ignacego Kraszewskiego, zorganizowane przez Gminę Polską oraz kilka innych polskich towarzystw chicagowskich ${ }^{23}$.

Pomysły w kierunku stworzenia centralnej organizacji polskiej w Stanach Zjednoczonych od początku dokonywały się pod wpływem wzajemnych kontaktów między emigracją amerykańską a europejską ${ }^{24}$. Stanisław Osada, autor monografii Związku Narodowego Polskiego, konstruując genezę tej instytucji pisał o tamtym okresie:

Liczne grono najwybitniejszych wychodźców polskich, na długie lata przed powstaniem Związku, pracowało jak mogło, porozumiewając się często i stale z niedobitkami patriotów polskich w Europie nad pobudzeniem świadomości narodowej w napływających coraz liczniej masach wychodźstwa zarobkowego, zanim dojrzał plan ufundowania organizacji narodowej, i zanim do założenia jej przyszło ${ }^{25}$.

Środowiska inteligencji krajowej nie angażowały się szerzej w te działania, traktując wychodźstwo zarobkowe jako bezpowrotnie utraconą tkankę polskości ${ }^{26}$. Masowemu wychodźstwu sprzeciwiały się nie tylko gazety krajowe, np. „Czas”, „Gazeta Polska” [Czerniowce], ale też pisma emigracyjne, takie jak „Ojczyzna” czy „Głos Wolny”27. Po drugiej stronie oceanu Henryk Kałussowski, jeden z czołowych przywódców polskiej emigracji w Stanach Zjednoczonych lat 40. i 50. XIX wieku i do niedawna przedstawiciel powstańczego Rządu Narodowego w USA, był jedną z osób czynnie zaangażowanych w agitację przeciw masowej emigracji: „kto pierwszy nakłonił lud nasz do wychodźstwa wart dna piekła [...]” - pisał, obserwując nędzę imigrantów, w jednym z listów do Romualda J. Jaworowskiego ${ }^{28}$.

${ }^{22}$ H. FlorkowsKa-Frančić, Uroczystości rapperswilskie 1868-1918, „Rocznik Biblioteki Narodowej" 32(1996), s. 267- 280.

${ }^{23}$ W. Plater, Polacy w Ameryce i jubileusz Kraszewskiego, „Ogniwo” 12 XI 1879, s. 2; S. OSADA, Historia, s. 87-94; H. WerESZYCKI, Międzynarodowe echa jubileuszu Kraszewskiego w 1879 roku, „Dzieje Najnowsze” 1974, z. 3, s. 3-20.

${ }^{24}$ W. KruszKa, Historia polska w Ameryce. Początek, wzrost i rozwój dziejowy osad polskich w Pótnocnej Ameryce (w Stanach Zjednoczonych i Kanadzie), t. IV, Milwaukee 1905, s. 6; H. FLoRKowsKa-Frančić, Agaton Giller i powstanie Związu Narodowego Polskiego w Stanach Zjednoczonych (1880), „Przegląd Polonijny” 1979, z. 1, s. 79-84.

${ }^{25}$ S. Osada, Prośba do Sz. Braci Związkowych, „Zgoda” 23 II 1905, s. 1.

${ }^{26}$ A. STоcкA, Stany Zjednoczone w świetle prasy warszawskiej z lat 1865-1877, Białystok 2013.

${ }^{27}$ [Bez tyt.], „Ojczyzna” 19 III 1865, s. 1; Część literacko-artystyczna. Teatr, „Czas” 7 VI 1876, s. 1; F. STASIK, Polska emigracja zarobkowa w Stanach Zjednoczonych Ameryki 1865-1914, Warszawa 1985, s. 24.

${ }^{28}$ BN, sygn. Rkps 8920, Henryk Kałussowski do Romualda Jaworowskiego, Washington $21 \mathrm{~V}$ 1869, k. 21. 
Przenikanie nurtów ideowych emigracji europejskiej do amerykańskiej diaspory dokonywało się przede wszystkim na styku personalnych powiązań. Kontakty przedstawicieli emigracji europejskiej ze swoimi odpowiednikami na drugiej półkuli ograniczały się do wąskiego grona osób. Dawne polskie ugrupowania polityczne w Stanach Zjednoczonych starające się przełamać izolację i porozumieć $\mathrm{z}$ europejskimi organizacjami emigracyjnymi już nie istniały. Zainteresowanie wychodźstwem polsko-amerykańskim prasy emigracyjnej ograniczało się wyłącznie do drukowania not informacyjnych oraz artykułów, w których podnoszono konieczność przeciwdziałania masowemu wychodźstwu, widząc w nim utratę sił narodowych. Do najbardziej aktywnych działaczy przejawiających różne stopnie zainteresowania rodakami mieszkającymi w Stanach Zjednoczonych, należeli obok Agatona Gillera i Władysława Platera także Zygmunt Miłkowski²9, Stefan Buszczyński ${ }^{30}$, Alfred Barwiński ${ }^{31}$, Józef Ignacy Kraszewski ${ }^{32}$ oraz Maria Konopnicka $^{33}$. Wydaje się, że największe znaczenie, jeśli idzie o pomysł na zorganizowanie polskiej diaspory za oceanem, miał Agaton Giller.

Giller, podobnie jak Plater, Kraszewski, a także inni działacze emigracyjni, wiedzę o Polonii czerpali z korespondencji nadsyłanych z Ameryki oraz tamtejszych pism polskojęzycznych, które regularnie nadsyłano do Rapperswilu ${ }^{34}$. Szczególną rolę w kształtowaniu obrazu polskiej diaspory amerykańskiej odegrał wspomniany Henryk Kałussowski oraz Julian Horain. Obaj dzielili się wiedzą i opiniami na temat sytuacji imigrantów nie tylko w listach prywatnych, ale przede wszystkim w specjalnych korespondencjach pisanych do prasy krajowej ${ }^{35}$. Prawdopodobnie in-

${ }^{29}$ H. FlorkowsKa-Frančı́́, Kontakty Zygmunta Miłkowskiego z Poloniq amerykańska, „Studia Śląskie" 57(1998), s. 155-167.

${ }^{30}$ M. Dynowska, Buszczyński Stefan, [w:] Polski Stownik Biograficzny, t. III, Kraków 1937, s. 148; K.K. DASZYK, Strażnik romantycznej tradycji. Rzecz o Stefanie Buszczyńskim, Kraków 2001, s. $84-86,98$.

${ }^{31}$ BN, sygn. Rkps 10117, Alfred [Józef] Barwiński do Władysława Platera, Bruksela 30 VII 1880, k. 9; tenże do Władysława Paltera, Bruksela 17 VIII 1880, k. 15.

${ }^{32}$ H. Florkowska-Frančić, M. Frančić, Amerykańscy korespondenci Józefa Ignacego Kraszewskiego. Portret zbiorowy Polonii, cz. I/II, Przegląd Polonijny” 1986, z. 1, s. 5-22, z. 2, s. 5-24.

33 Sz. DeptuŁA, Więzy Konopnickiej z Polonia amerykańska, Warszawa 1960.

${ }^{34}$ BN, sygn. Rkps I 6544, Agaton Giller: II Noty i wypiski z gazet i różnych pism dla mego użytku, Rapperswil 1897, k.19, 26, 32-36, 40, 62-63, 71, 121, 130-131, 138-139, 150. Wypisy stanowią głównie zestawienia statystyczne dotyczące Polaków w Ameryce oraz relacji o tworzeniu nowych parafii polskich, zrobione zostały głównie na podstawie „Gazety Katolickiej” „Gazety Polskiej” oraz „Przyjaciela Ludu”.

35 H. Kalussowski, Ostrzeżenie przeciw wyjeżḋ̇aniu do Ameryki, „Głos Wolny” 20 VIII 1864 , s. 197; BN, sygn. Rkps IV 8920, Henryk Kałussowski do L. Koeniga 15 XII 1865 i 30 I 1866, k. 3639. Listy o Ameryce pisane przez Henryka Katussowskiego do Juliana Horaina, „Tygodnik Ilustro- 
formacje od Kałussowskiego posłużyły Kraszewskiemu do napisania relacji o polskiej emigracji w Stanach Zjednoczonych, która ukazała się w „Rachunkach”36.

Pod koniec życia A. Giller stał się najbardziej aktywnym politycznym emigrantem z Europy Zachodniej kontaktującym się regularnie z diasporą polsko-amerykańską. Po powstaniu styczniowym miał ugruntowaną pozycję w środowiskach emigracji polskiej. Jego sojusznikami po stronie amerykańskiej stali się czołowi przywódcy lokalnych wspólnot polonijnych w Nowym Jorku, Filadelfii, Chicago, Milwaukee i Kalifornii. Do grupy tej należeli m.in.: Juliusz Andrzejkowicz, były członek Zjednoczenia Emigracji Polskiej z 1866 r., Ignacy Wendziński, redaktor „Przyjaciela Ludu” z Milwaukee, Władysław Dyniewicz, wydawca „Gazety Polskiej w Chicago”, Aleksander Bednawski, uczestnik powstania listopadowego, potem członek TDP, oraz Stanisław Artwiński, redaktor nowojorskiego „Ogniwa”. Wiele informacji czerpał także od Sygurda Wiśniowskiego, podróżnika i korespondenta pism krajowych, przebywającego w Ameryce na przełomie lat 70. i 80. Niewykluczone, że to właśnie Giller namówił go do wyjazdu na Bałkany i do Turcji, by poznać tamtejsze stosun$\mathrm{ki}^{37}$. Szczególne zainteresowanie, jakie okazywał wychodźcom polskim w Stanach Zjednoczonych, usytuowały go na pozycji nieoficjalnego przywódcy-opiekuna Polonii amerykańskiej. Stał się osobą, która reprezentowała oraz legitymizowała aspiracje narodowe tamtejszego wychodźstwa. Korzyści z takiego stanu rzeczy odnosily również rozbite i pozbawione centralnego przywództwa organizacje emigracyjne w Europie, które w ten sposób częściowo kompensowały sobie utratę wpływu w kraju, tak by „nie mając lekarstwa na zło wychodźstwa [...] przynajmniej już tych co w Ameryce osiedlonych Polaków ratować od wynarodowienia [i] zachować dla Polski"38.

Kiedy zmniejszyła się nieco obawa o związki wychodźstwa z Macierzą, a coraz więcej obserwatorów społecznych procesów dochodziło do wniosku, że pewne sprawy są nieuniknione, pojawiły się pierwsze głosy zachęcające do szukania pożytku z migracji zamorskich. Zauważono, że Polonia amerykańska krystalizuje się powoli w odrębną samoświadomą grupę społeczną, wykazując na tyle dojrzały stopień solidarności i świadomość celów, by móc stworzyć przyczółek dla politycznych działan ${ }^{39}$. Rozwijającemu się tam systemowi społecznemu rysowały się pomyślne

wany" 3 VI 1871, s. 272; M. FranČÍ, Julian Horain i jego korespondencja ze Stanów Zjednoczonych z lat 1871-1880, „Przegląd Polonijny” 1986, z. 4, s. 51-75.

${ }^{36}$ Bolesławita [Józef Ignacy Kraszewski], Z roku 1867. Rachunki, rok II, cz. 2, Poznań 1868, s. 97-136. Krytycznie na temat wartości poznawczej tego źródła wyraził się J. Borejsza, Emigracja, s. 19. Por. Z roku 1866 Rachunki przez B. Bolestawite, „Głos Wolny” 22 V 1867, s. 560-561.

37 Listy Sygurda Wiśniowskiego do Kraszewskiego, „Pamiętnik Literacki” 2009, z. 4, s. 145.

${ }^{38}$ Zawsze ci sami, „Zgoda” 30 VII 1896, s. 1.

39 Wieniec pamiątkowy pótwiekowej rocznicy powstania listopadowego obchodzonej 29 listopada 1880 r., red. A. Giller, Rapperswil 1881, s. 740-741. 
perspektywy na realizację rozmaitych zadań narodowych, choć nie formułowano jeszcze konkretnej orientacji politycznej dla całego tamtejszego wychodźstwa, by nie obarczać go zbyt ryzykowną misją polityczną. Inna sprawa, że emigranci nawiązujący do tradycji TDP nigdy nie doceniali dyplomacji jako środka do wyzwolenia. Zabiegi dyplomatyczne nie korespondowały z przekonaniem, iż Polacy są w stanie wywalczyć swoją niepodległość bez oglądania się na obcą pomoc.

Z pewnością słaby potencjał intelektualny diaspory polskiej w Stanach Zjednoczonych nie pozwalał jeszcze na zbyt śmiałe inicjatywy niepodległościowe. Dostrzegano tam co prawda jednostki oddane sprawie polskiej, ale większość społeczności polonijnej była bierna politycznie, a jej tożsamość narodowa uzewnętrzniała się wyłącznie przez zachowanie języka i tradycji religijnej ${ }^{40}$. Struktura społeczna tamtejszej Polonii była inna od tej w Europie, gdzie niewielkie ilościowo skupiska Polaków doprowadziły tam, mimo wewnętrznych waśni, do bujnego rozwoju organizacyjnego. W Stanach Zjednoczonych z kolei odsetek ludnościowy był nieprawdopodobnie wyższy w porównaniu ze Starym Kontynentem, lecz życie instytucjonalne niemrawe i pozbawione większego znaczenia. Istniały jednak ośrodki miejskie, gdzie nieliczne kolonie polskie osiągnęły wyższy stopnień zorganizowania (Nowy Jork, Filadelfia, Chicago, Milwaukee, San Francisco). W tych przyczółkach podjęto inicjatywy, aby zainicjować projekt centralnej instytucji, obejmującej swoim zasięgiem całe życie organizacyjne młodego polsko-amerykańskiego społeczeństwa. Władze takiej instytucji chciały mówić w imieniu wszystkich Polaków w Stanach Zjednoczonych, a także podejmować decyzje odnośnie do przyszłych kierunków politycznych emigracji polskiej w Europie i świecie. Opracowanie szczegółowe tego projektu, któremu Giller poświęcił ostatnie lata życia, okazało się najtrwalszą ze wszystkich jego inicjatyw emigracyjnych.

Poglądy Agatona Gillera na Polonię amerykańską ewoluowały. Początkowo przyłączał się on do tych, którzy upatrywali w zamorskim wychodźstwie tragedię narodową. Popierał zwolenników chwytania się wszelkich środków hamujących napływ emigracji z kraju do Stanów Zjednoczonych i tego, ,aby ci, co się tam znajdują nie sprowadzali swoimi listami nowych emigrantów"41. Z czasem jednak nauczył się dostrzegać potencjał narodotwórczy nowej emigracji, mimo iż do końca

${ }^{40}$ H. KuBIAK, Rodowód narodu amerykańskiego, Kraków 1975, s. 44-46; A. BrożEK, Świadomość polskiej grupy etnicznej w Stanach Zjednoczonych w latach 1854-1939, „Kwartalnik Historyczny" 84(1977), z. 2, s. 337-339.

${ }^{41}$ Zakład im. Ossolińskich [dalej: Ossol.], sygn. Rkps 5010 II Agaton Giller do Alojzego Teleżyńskiego, Rapperswil 23 IX 1881, k. 17. Por. BJ, sygn. Rkps 3685 III, t. II, Agaton Giller do Jana Nepomucena Janowskiego, Bendlikon 18 III 1865, k. 260-261; W. Plater, Projekt kolonii polskiej w Ameryce, „Ojczyzna” 16 IV 1865, s. 4; H. FlorkowsKA, Struktura polskiej emigracji politycznej w Szwajcarii w latach sześćdziesiąych XIX, Wrocław 1976, s. $42-43$. 
krytycznie patrzył na osoby i instytucje zachęcające do wyjazdu na drugą półkulę. Ostatecznie kształt zapatrywań na kształt i rolę tamtejszej diaspory na polu działań organizacyjno-narodowych wyartykułował w liście do Polaków w Ameryce wydrukowanym najpierw w lwowskiej „Gazecie Narodowej”, następnie w „Gazecie Polskiej w Chicago" i w końcu w osobnej broszurze ${ }^{42}$.

$\mathrm{Z}$ prośbą o połączenie istniejących stowarzyszeń lokalnych w szerszą organizację zwracali się do Gillera również co światlejsi przedstawiciele Polonii. Wielu z nich odczuwało potrzebę unifikacji wychodźstwa pod wspólnym sztandarem i podejmowało próby w tym kierunku ${ }^{43}$. Kilku z nich pisało w tej sprawie do Muzeum w Rapperswilu, ,jako instytucji, w około której skupia się znaczna część działania emigracyjnego, prosząc o radę, pośrednictwo i o pomoc przy przeprowadzeniu ogólnej organizacji” ${ }^{44}$. Stanisław Osada przekazał w oficjalnej historii ZNP, że pisali do Muzeum Julian Lipiński, Teofila Samolińska oraz Henryk Kałussow$\mathrm{ski}^{45}$. Przetrwał do naszych czasów jedynie list Samolińskiej przedrukowany przez Artura Waldo ${ }^{46}$.

Nie ulega wątpliwości, że „nowa” emigracja w Ameryce potrzebowała autorytetu, który byłby w stanie potwierdzić jej aspiracje i zdolność do zorganizowania oraz utrzymania sprawnie działającej instytucji narodowej na miarę swoich możli-

${ }^{42}$ List Agatona Gillera o organizacji Polaków w Ameryce, „Gazeta Polska w Chicago” 1879; S. Osada, Historia, s. 97. Analizę zawartości listu Gillera przeprowadziła H. Florkowska-Frančić, zob. H. Florkowska-Frančić, Emigracyjna działalność Agatona Gillera po Powstaniu Styczniowym, „Studia Polonijne” 10(1986), s. 158-163.

${ }^{43}$ S. Osada, Historia, s. 39-42; H. FlorkowsKa-Frančić, Emigracyjna działalność, s. 157; A. Brożek, Próby zjednoczenia Polonii amerykańskiej i ich ideologie, [w:] Polonia amerykańska. Przeszłość i współczesność, red. H. Kubiak, Wrocław 1988, s. 151-152.

${ }^{44}$ List Agatona Gillera, s. 53

${ }^{45}$ S. OSADA, Historia, s. 107.

${ }^{46}$ A. Waldo, Teofila Samolińska Matka Związu Narodowego Polskiego w Ameryce, Chicago 1980, s. 12-13. Trudno powiedzieć, z jakich powodów Andrzej Brożek i Donald Pienkos uznali, że Henryk Kałussowski kontaktował się z Gillerem w sprawie organizacji. A. BrożEK, Polonia amerykańska 1854-1939, Warszawa 1977, s. 62; D. Pienkos, P.N.A. Centennial History of the Polish National Alliance of the United States of North America, Boulder 1984, s. 47-48; M. TYrowicz, Katussowski Henryk, [w:] Polski Stownik Biograficzny, t. XI, Wrocław 1964-1965, s. 506; K. MuRZYNOwsKa, Henryk Korwin-Katussowski, (1806-1894), „Problemy Polonii Zagranicznej” 4(1964-65), s. 128. Nie znajdujemy żadnych dowodów na to, aby Kałussowski w tym czasie nawiązywał kontakty z Rapperswilem w sprawie powołania do życia narodowej organizacji; również Giller nie wspominał o korespondencji z Kałussowskim w tym okresie. Prawdopodobnie wyłącznie przypuszczenia Stanisława Osady wpisane na marginesie jego historii Związku Narodowego Polskiego spowodowały, że uznany on został przez ww. badaczy za jednego z założycieli ZNP. Potwierdza to H. Florkowska-Frančić, pisząc, iż oprócz listu Teofili Samolińskiej: „Inne listy z Ameryki pisane do Gillera nie są znane" - H. FlorkowsKa-Frančić, Emigracyjna działalność, s. 158 (przyp. 27). 
wości. Agaton Giller spełniał wszystkie warunki, aby ubiegać się o zaufanie i szacunek w oczach wychodźstwa polskiego. Jego biografia polityczna ugruntowała mu nazwisko symbolizujące Polakom za oceanem system wartości oparty na wzorcach ukształtowanych przez Wielką Emigrację. Miał spore doświadczenie w tworzeniu struktur organizacyjnych na wychodźstwie, rozległe kontakty z osobami reprezentującymi różne środowiska, ale przede wszystkim posiadał rzadką w polskiej emigracji cechę, jaką było szukanie kompromisów i skłonność do godzenia zwaśnionych stron w imię szlachetnej sprawy. Jeszcze w latach 60. na łamach „Ojczyzny" prowadził dyskusje i podejmował próby tworzenia towarzystw samopomocowych, starając się dopasować formy organizacyjne wychodźstwa do zmieniających się warunków ${ }^{47}$. Wtedy też bardziej zainteresował się emigracją amerykańską ${ }^{48}$. W omawianym okresie był już co prawda działaczem starej daty, ale nad wyraz aktywnym. Trudno jednoznacznie określić, w jakim stopniu przyczynił się do założenia Związku Narodowego Polskiego. On sam w korespondencjach niejednokrotnie uznawał swoje działania za decydujące w powstaniu tej instytucji ${ }^{49}$, choć miał wątpliwości, czy jest w stanie podołać postawionemu zadaniu. Z pewnością „List” był znany czytelnikom polskiej prasy w Stanach Zjednoczonych i przyczynił się do wzmocnienia postaw patriotycznych wśród Polonii. O tym, że miał on jeśli nie decydujący, to na pewno istotny głos w tworzeniu oblicza ideowego nowej organizacji, świadczy fakt dużego zaangażowania Gillera w propagowanie ZNP na łamach prasy polsko-francuskiej czytanej za oceanem ${ }^{50}$.

Kluczową kwestią, która miała zagwarantować powodzenie tego projektu, było zaproszenie do współpracy polonijnych środowisk kościelnych. Szukając środków zaradczych wobec rysujących się już wówczas podziałów ideologicznych, postulował oparcie nowej instytucji na strukturach parafialnych kierowanych przez narodowo uświadomiony kler. Dodać trzeba, że emigranci polityczni nie mieli jednak dużych szans na rozwijanie działalności w środowisku parafialnym. Owszem, często w takich wspólnotach można było spotkać uczestników powstań narodowych, ale nie wszyscy decydowali się na zakładanie struktur odrębnych wobec towa-

${ }^{47}$ H. FlorkowsKa-Frančić, Emigracyjna działalność, s. 34-35.

48 Ossol, sygn. Rkps 4397 I, Agaton Giller do J. Łukaszewskiego, Weyssenburg 13 VI 1866, k. 102 .

49 Ossol, sygn. Rkps 4397 I, Agaton Giller do Juliana Łukaszewskiego, Rapperswil 10 IV 1880, k. 139.

${ }^{50}$ Już od momentu powstania „Kuriera Paryskiego” z inspiracji A. Gillera drukowano tam informacje o Związku Narodowym Polskim, dając wyrazy solidarności z rodakami za oceanem. Zob. W. Osuch, Odezwa do redaktorów gazet polskich i wszystkich rodaków w Europie, „Kurier Paryski” 1 X 1881, s. 7. Giller promował też Związek Narodowy Polski do gazet krajowych, Ossol, sygn. Rkps 5010 II, Agaton Giller do Alojzego Teleżyńskiego, Rapperswil 23 II 1881, k. 17. 
rzystw kościelnych. Dlatego też szczególną rolę w koncepcji Gillera mieli odgrywać duchowni jako niekwestionowani przywódcy Polonii. W pierwszej kolejności liczył na pomoc zmartwychwstańców ${ }^{51}$. Wymyślił on wzór idealnego proboszcza, który powinien być „,człowiekiem tolerancji, którą prawo amerykańskie tam wysoko podniosło i uczyniło obowiązującym dla wszystkich obywateli, powinien być przyjacielem nieograniczonej wolności i form republikańskich i nic wspólnego nie mieć z polityką pewnej kategorii księży w Europie, których ideałem są średnie wieki i którzy wojując ciemnymi namiętnościami, nienawidzą postępu i zasad nowoczesnego państwa, posiadającego jedynego prawdziwego reprezentanta w tej właśnie republice Stanów Zjednoczonych, które dzisiaj dla kościoła katolickiego są jedynie pewnym i bezpiecznym przytułkiem" 52 . Starał się zapobiec potencjalnym trudnościom w realizowaniu tych zamiarów, i - jak się okazało - jego obawy nie były bezpodstawne. Koniec końców musiał uznać fakt, iż wersja katolicyzmu polskiego w Stanach Zjednoczonych w tym czasie odbiegała od jego oczekiwań, na co zwrócił uwagę choćby Henryk Sienkiewicz, który podczas swojego pobytu w Ameryce porównywał tamtejsze zasady współżycia polskich wspólnot parafialnych do wzorów średniowiecznych ${ }^{53}$. Z drugiej strony zdawał sobie sprawę, że działalność elit polskich w Stanach Zjednoczonych uznających zarówno w życiu społecznym, jak i pracy narodowej prymat Kościoła, nabrało już na tyle ultraklerykalnego charakteru, że procesu tego nie da się łatwo powstrzymać.

Pogodzony z koniecznością współpracy ze wspólnotami parafialnymi, jak tylko mógł, starał się Giller zespolić sferę religijną z narodową. Służyć temu miały m.in. „obchody narodowe, wykłady publiczne z dziejów i literatury polskiej, czytelnie, biblioteki i dziennikarstwo" 54 . Punktem docelowym tak przyjętej koncepcji miała być już innego rodzaju wspólnota - gmina ${ }^{55}$. Organizacja taka nie stanowiła

${ }^{51}$ Prasa periodyczna polska poza granicami kraju, „Gazeta Narodowa” 8 VI 1872, s. 1.

${ }^{52}$ List Agatona Gillera, s. 48-49.

${ }^{53}$ H. Sienkiewicz, Listy z podróży do Ameryki, oprac. Z. Najder, Warszawa 1956, s. 584.

${ }^{54}$ List Agatona Gillera, s. 37.

${ }_{55}$ Pomysł ten nawiązuje do koncepcji gmin polskich, które Giller organizował w Szwajcarii w ramach federacyjnego systemu, choć na gruncie amerykańskim miał mieć szersze zadania. Gminy te oczywiście nie miały nic wspólnego z koncepcjami gmin Lelewela, zob. Cz. LEŚNIEwSKI, Gmina w Polsce odrodzonej wedlug projektów Towarzystwa Demokratycznego Polskiego z lat 1840-41, [w:] Studia historyczne ku czci Stanisława Kutrzeby, t. II, Kraków 1938, s. 483-516; E. KostoŁowsKi, Studia nad kwestia włościańska w latach 1846-1864 ze szczególnym uwzględnieniem literatury politycznej, Lwów 1938, s. 265-269. Bliżej jej już było do koncepcji gmin u Józefa Hauke-Bosaka, które zakładał na emigracji, m.in. w Rumunii, gdzie Julian Łukaszewski w latach 1866-1869 tworzył gminy podległe Komitetowi Reprezentacyjnemu Emigracji Polskiej. Zob. A. WoJciechowsKa, Protokót jako świadectwo komunikacji wspólnotowej $w$ drugiej połowie XIX wieku. Studium genologiczne, Zielona Góra 2012, s. 16. 
celu samego w sobie, ale miała koordynować wszelkie przejawy życia społecznego Polonii. Nie znajdziemy natomiast dowodów na tezę postawioną przez Krzysztofa Groniowskiego, że w zamierzeniu Gillera taka instytucja miała przypominać galicyjski Wydział Krajowy ${ }^{56}$. W wymiarze społecznym jej zadaniem było wypromowanie najbardziej inteligentnych jednostek do udziału w życiu politycznym Stanów Zjednoczonych, propagujących interesy polskie w polityce amerykańskiej.

Projekt Gillera, mimo że przemyślany, opierał się na zbyt optymistycznych wyobrażeniach o polskiej emigracji za oceanem. Amerykańska zbiorowość polonijna będąca in statu nascendi, nie miała w tym okresie potencjału, jaki jej Giller przypisywał. Jego przekonanie o dojrzałości polonijnych struktur społecznych do stworzenia jednorodnego masowego ruchu narodowego miało charakter życzeniowy, ponieważ co najmniej do końca XIX stulecia polska grupa etniczna w USA pozornie było jednorodna. Ludność migrująca z polskich wsi, miast i miasteczek pochodziła $\mathrm{z}$ różnych regionów kraju, reprezentowała różną mentalność i stopnie wykształcenia, a także uświadomienia narodowego. Jeszcze większe podziały panowały w grupach przywódczych. To, co możemy nazywać ówczesną Polonią amerykańską, istniało na zasadzie luźnych formacji wspólnotowych o niejednolitych cechach kulturowych i etnicznych. Przez długi czas te grupy nie były w stanie same z siebie stworzyć instytucji ponadlokalnych, z którymi większość imigrantów mogła się identyfikować ${ }^{57}$. Musiało minąć kilka dekad, nim polscy emigranci polityczni w Stanach Zjednoczonych mogli wypracować nowe formy organizacyjne dostosowane do warunków amerykańskich. Ostatecznie wzorując się na amerykańskich towarzystwach ubezpieczeniowych, stworzono model organizacyjny, który przyjął się także w innych wspólnotach etnicznych Ameryki tego czasu ${ }^{58}$. Jego wykładnią były instytucje ubezpieczeniowe, działające na prawach stanowych, których władze prowadziły szereg zadań społecznych, politycznych, edukacyjnych oraz ekonomicznych na rzecz interesów danej wspólnoty etnicznej. Charakter tych zadań wynikał najczęściej z przyjęcia ideologii narodowych, formułowanych bądź w krajach pochodzenia, bądź miejscu osiedlenia określonych grup etnicznych.

Nowa odsłona kontaktów między emigracją polską z Europy Zachodniej a polsko-amerykańską diasporą nastąpiła po założeniu Związku Narodowego Polskiego

${ }^{56}$ K. Groniowski, Polonia w Stanach Zjednoczonych u schyłku XIX w. Pozycja społeczna i postawy polityczne, „Przegląd Polonijny” 2(1976), nr 1, s. 17.

57 Zjednoczenie Polskie Rzymsko-Katolickie było taką instytucją tylko z nazwy.

58 John Bodnar przytacza argumenty za i przeciw tezie, że podstawowe wzory tworzenia się etnicznych organizacji należy szukać w europejskich tradycjach zrzeszeń wzajemnej pomocy, istniejących wśród chłopów mieszkających w Europie Wschodniej, Środkowej i Południowej, zob. G. BABIŃSKI, Więź etniczna a procesy asymilacji. Przemiany organizacji etnicznych: zagadnienia teoretyczne i metodologiczne, Warszawa-Kraków 1986, s. 101. 
w 1880 r. Wiązała się głównie z rozwojem idei Skarbu Narodowego wymyślonej przez Agatona Gillera, a rozwiniętej przez Zygmunta Miłkowskiego w broszurze Rzecz o obronie czynnej o skarbie narodowym ${ }^{59}$. Ważną płaszczyzną instytucjonalnych kontaktów między obiema emigracjami w latach 90. XIX stulecia była współpraca w ramach Związku Wychodźstwa Polskiego $0^{60}$ oraz Ligi Polskiej ${ }^{61}$. Przełomowym momentem wzajemnych relacji była wizyta w Stanach Zjednoczonych Zygmunta Balickiego i Karola Lewakowskiego. Delegaci europejscy, reprezentujący Muzeum Polskie w Rapperswilu oraz polityczne interesy Ligi Narodowej, starali się za zgodą Związku Narodowego Polskiego przejąć fundusze gromadzone na Skarb Narodowy przez Polonię amerykańską ${ }^{62}$. Misję zakończoną wówczas połowicznym sukcesem kontynuował Z. Miłkowski, który odwiedził polskie osady w Ameryce w 1900 r., licząc na to, że blisko dwumilionowa diaspora polska za oceanem może być realną siłą polityczną ${ }^{63}$. W tym czasie zainteresowanie Polonią amerykańską zaczęły wykazywać także instytucje krajowe, czego efektem był przyjazd do Stanów Zjednoczonych Emila Dunikowskiego, lwowskiego profesora, geologa i podróżnika ${ }^{64}$.

Koniec lat 70. i początek 80. XIX wieku był niewątpliwie okresem ważnym w przełamywaniu osamotnienia oraz izolacji Polonii amerykańskiej. Do tego czasu wszystkie doniosłe momenty w dziejach zarówno Wielkiej Emigracji, jak i kraju dochodziły tam słabym echem. Sytuację tę zmieniło kilka czynników: przede wszystkim masowa emigracja zamorska przy jednoczesnym kryzysie organizacyjno-ideowym emigracji na zachodzie Europy. Rozwijaniu wzajemnych kontaktów sprzyjał także gwałtowny rozwój technologiczny w dziedzinie komunikacji morskiej oraz telegraficznej. Istotne $\mathrm{w}$ tych relacjach było podtrzymywanie myślenia o zadaniach obu wspólnot narodowych w kontekście walki o niepodległość. Walka ta miała mieć nie tylko charakter gry dyplomatycznej, ale nabierała niekiedy wymiaru metafizycznego starcia dobra ze złem. Stąd też wynikało przekonanie o przodującej roli polskiej emigracji już nie tylko w Europie Zachodniej, ale i Sta-

59 Z. MiŁкоwsKi, Rzecz o obronie czynnej i skarbie narodowym, Paryż 1887.

${ }^{60} Z$ Zw iazek] N[arodowy] P[olski] a Wych[odźstwo] P[olskie] w Europie, Zgoda 22 VIII 1894, s. 1.

${ }^{61}$ K. Groniowski, Polonia amerykańska a Narodowa Demokracja (1893-1914), „Kwartalnik Historyczny" 79(1972), nr 1, s. 25-27.

${ }^{62}$ S. PastuszKa, Karol Lewakowski a Skarb Narodowy, „Roczniki Dziejów Ruchu Ludowego” 1973, nr 15, s. 192-194.

${ }^{63}$ Z. Mıєкоwski, Opowiadanie z wędrówek po koloniach polskich w Ameryce Pótnocnej, Paryż 1901.

${ }^{64}$ Emil Habdank-Dunikowski, „Zgoda” 31 VIII 1892, s. 4; [Bez tyt.], „Zgoda” 7 IX 1891, s. 1; [Bez tyt.], „Zgoda” 14 IX 1892, s. 1; [Bez tyt.], „Zgoda” 21 IX 1891, s. 1. 
nach Zjednoczonych. Wizję tę najpełniej wyartykułowano w „Gazecie Polskiej” ukazującej się w Czerniowcach:

[...] w Ameryce formuje [się] poważne liczbą polskie wychodźcze ciało polityczne. Ażeby to ostatnie było w możności zużytkowania się na korzyść Ojczyzny, koniecznym jest w Europie niezależne, silnie zorganizowane i ze świadomością rzeczy działające Ojczyzny tej zastępstwo. Boć wychodźstwo polskie w Ameryce samo przez się bezpośredniego udziału w sprawach europejskich brać nie może. Przeszkadza w tym położenie geograficzne nie dozwalające mu zastępować, a raczej wyręczać kraju w takich, jak ruchy rewolucyjne i zajścia wojenne razach. W razach podobnych działalność spada ciężarem całym na emigrację polską, przebywającą w Europie, wyznaczając jej z góry rolę odpowiednią w stosunku, z jednej strony, do kraju, z drugiej, do wychodźstwa polskiego w Ameryce. Jakąż jest ta rola? Odpowiada ona tej, którą obowiązany jest na polu bojowym pełnić batalion zajmujący środek linii. Wyraża się on obowiązkiem czucia do skrzydeł tak lewego jak prawego. Niedopełnienie tego obowiązku najsmutniejsze sprowadza następstwa. Emigracja polska w Europie pełni funkcję owego batalionu środkowego a czucia do prawego i czucia do lewego wyraz dla niej, w chwili bieżącej, kiedy Europa pozostaje jeszcze w stanie wyczekiwania wypadków, znajduje się na drodze organizacyjnej. Organizować się powinna sama i pobudzać do organizowania się z jednej strony, obywatelstwo krajowe, $\mathrm{z}$ drugiej obywatelstwo polskie w Ameryce. Pojawienie się tego ostatniego rozszerzyło jej działalność i w miarę rozszerzenia spotęgowało odpowiedzialność. Wejście z nią w stosunki bliskie a ścisłe obejmujące porozumienie się w całej sferze zabiegów przygotowawczych, nasuwa tak samo przez się niezbędnie a nagląco ${ }^{65}$.

Stopniowo zatem emigracja polska w Stanach Zjednoczonych nabrała przekonania, że została powołana do odegrania znaczącej roli politycznej, i dobrze się w niej czuła. Bez względu na oceny efektów współpracy między emigracją europejską a amerykańską uznano Polaków w Ameryce w omawianym okresie za potrzebnych dla kraju. Sposoby pełnienia służby ojczyźnie wymagały jednak negocjacji. Już od czasu, kiedy próbowano pod egidą Zjednoczenia Emigracji Polskiej zunifikować wszystkie polskie środowiska na świecie, ścierały się ze sobą dwie koncepcje konsolidacyjne: federacyjna, oparta na wzorach szwajcarskich, i centralistyczna, której przewodzili paryscy emigranci ${ }^{66}$. Niewątpliwie Polacy w Ameryce, w przeciwieństwie do Polaków w Europie, musieli inaczej rozłożyć akcenty podejmując działania na rzecz kraju. Od początku w czołowych ponadlokalnych amerykańskich organizacjach polonijnych zaznaczał się dylemat związany ze stopniem zaangażowania w sprawy polityki europejskiej. Jedni mobilizowani przez

${ }^{65}$ O emigracji polskiej, „Gazeta Polska” (Czerniowce), 8 I 1891, s. 1.

${ }^{66}$ H. FlorkowsKa-FrančIć, Polacy w Szwajcarii po powstaniu styczniowym wobec kraju azylu, „Przegląd Polonijny” 1992, z. 3, s. 40. 
emigrację z Europy chcieli powielać schematy działań prowadzonych na Starym Kontynencie, inni ulegając stopniowej asymilacji, starali się powściągać te zapędy na korzyść pracowania na rzecz tworzącej się polsko-amerykańskiej społeczności. Dylemat ten widoczny był przy formułowaniu celów prasy polsko-amerykańskiej. Możliwości realnego wpływu na politykę europejską były znikome, z kolei ogrom pracy nad uświadamianiem narodowym imigrantów, działalnością oświatową przerastał organizacje polonijne. Symboliczną pomoc w tym zakresie świadczyli emigranci z Europy, wysyłając m.in. polskie książki do lokalnych bibliotek w Ameryce zakładanych przez tamtejszych przywódców.

Niebawem rozwój życia organizacyjnego polonijnych wspólnot doprowadził do konfliktu między dwiema najliczniejszymi i najbardziej wpływowymi instytucjami wychodźczymi: Związkiem Narodowym Polskim i Zjednoczeniem Polskim Rzymsko-Katolickim. Spór ten okazał się równie ważny, o ile nie ważniejszy od ówczesnych swarów emigracyjnych w Europie. W Stanach Zjednoczonych bądź co bądź rodziła się poważna siła społeczna, której kierunki rozwoju, także politycznego, nie były bez znaczenia dla tzw. sprawy polskiej, nawet jeśli w świetle ówczesnych opinii mogły się wydawać nieistotne. Tym bardziej że spór dotyczył tego, czy Polonia amerykańska powinna angażować się w sprawy narodowe, czy też pozostawić je własnemu biegowi. W tym kontekście specyficzne uwarunkowania, w jakich żyli obywatele republikańskich instytucji polskiego pochodzenia, miały zasadniczy wpływ na formy pomocy, jakiej udzielali Macierzy na przełomie XIX i XX wieku, oraz intensywność utrzymywania łączności z wszelkimi ruchami niepodległościowymi na emigracji.

\section{BIBLIOGRAFIA}

\section{Źródła rękopiśmienne}

Biblioteka Jagiellońska

sygn. Rkps 3685 III - Korespondencja Jana Nepomucena Janowskiego

sygn. Rkps 6537 IV - Korespondencja Józefa I. Kraszewskiego. Seria III. Listy z lat 1863-1887

Biblioteka Narodowa

sygn. Rkps IV 8920 - Brulion listów Henryka Kałussowskiego

sygn. Rkps I 6544 - Agaton Giller: II Noty i wypiski z gazet i różnych pism dla mego użytku

sygn. Rkps 10117 - Fragment korespondencji Władysława Platera z 1880 roku

Biblioteka Polska w Paryżu

sygn. akc. Rkps 2692 - Władysław Plater do Henryka Bukowskiego, Villa Broelberg 28 VIII 1879 
Ossolineum

sygn. Rkps 5010 II - Korespondencja oraz papiery inż. Alojzego Teleżyńskiego 18731885

sygn. Rkps 4397 I - Listy dr Juliana Łukaszewskiego od różnych osób

\section{Źródla drukowane}

KŁYSZEWSKI W., Z moich wspomnień, Kraków 1961.

List Agatona Gillera o organizacji Polaków w Ameryce, Chicago 1879.

Listy Sygurda Wiśniowskiego do Kraszewskiego, „Pamiętnik Literacki” 2009, z. 4, s. 141 166.

MıŁkowski Z., Opowiadanie z wędrówki po koloniach polskich w Ameryce Północnej, Paryż 1901.

MıŁKowski Z., Rzecz o obronie czynnej i skarbie narodowym, Paryż 1887.

Roczne Zdanie Sprawy Zarządu Muzeum Narodowego w Rapperswilu z dn. 29 XI 1879, Zurych 1879.

SiENKIEwICZ H., Listy z podróży do Ameryki, oprac. Z. Najder, Warszawa 1956.

\section{Prasa}

„Czas” (Kraków) 1876

„Gazeta Narodowa” (Lwów) 1872

„Gazeta Nowojorska” 1874

„Gazeta Polska” (Czerniowce) 1890-1891

„Gazeta Polska w Chicago” [1877]

„Kurier Paryski” 1881

„Ogniwo” (Nowy Jork) 1879

„Ojczyzna” (Lipsk-Bendlikon) 1865

„Przegląd Wszechpolski” 1896

„Przyjaciel Ludu” (Milwaukee) 1880

„Tygodnik Ilustrowany” 1871

„Zgoda” (Chicago) 1894, 1896, 1905

\section{Opracowania}

BIDDISs M., Progress, prosperity, and positivism: cultural trends in mid-century, [w:] Themes in modern European history 1830-1890, ed. B. Waller, London-New York 1990, s. 190-212.

BrożeK A., Polonia amerykańska 1854-1939, Warszawa: Interpress 1977.

Brożek A., Próby zjednoczenia Polonii amerykańskiej i ich ideologie, [w:] Polonia amerykańska. Przeszłość i współczesność, red. H. Kubiak, Wrocław: Ossolineum 1988, s. $149-175$.

BrożEK A., Świadomość polskiej grupy etnicznej w Stanach Zjednoczonych w latach 1854-1939, „Kwartalnik Historyczny” 84(1977), z. 2, s. 333-353. 
Buchman A., Muzeum Polskie w Rapperswilu - dzieło emigracji postyczniowej, [w:] Emigracja postyczniowa 1863 roku, red. E. Niebelski, Lublin: Wydawnictwo KUL 2010, s. $195-204$.

BolesŁaWita [J.I. Kraszewski], Z roku 1867. Rachunki, rok II, cz. 2, Poznań 1868.

BolesŁawita [J.I. Kraszewski], Z roku 1868. Rachunki, Poznań 1869.

BoreJSZA J., Emigracja polska po powstaniu styczniowym, Warszawa 1866.

CioŁkoszowie L.A., Zarys dziejów socjalizmu polskiego, t. II, Londyn 1972.

DAszYK K.K., Strażnik romantycznej tradycji. Rzecz o Stefanie Buszczyńskim, Kraków: Historia Iagellonica 2001.

DeptuŁa Sz., Więzy Konopnickiej z Polonią amerykańską, Warszawa 1960.

Dunin-WąSOwicz K., Francuska opinia publiczna wobec sprawy polskiej i Polaków w latach 1885-1984, Wrocław: Ossolineum 1987.

Dynowska M., Buszczyński Stefan, [w:] Polski Słownik Biograficzny, t. III, Kraków 1937, S. 147-149.

FLORKOwsKa H., Struktura polskiej emigracji politycznej w Szwajcarii w latach sześćdziesiątych XIX wieku, Wrocław: Ossolineum 1976.

FlorkowsKa-Frančić H., Agaton Giller i powstanie Związku Narodowego Polskiego w Stanach Zjednoczonych (1880), „Przegląd Polonijny” 1979, z. 1, s. 79-89.

FlorkowsKa-FrančIć H., FrančIć M., Amerykańscy korespondenci Józefa Ignacego Kraszewskiego. Portret zbiorowy Polonii, cz. I/II, „Przegląd Polonijny” 1986, z. 1, s. 5-22, Z. 2, s. 5-24.

FlorkowsKA-Frančıć H., Kontakty Zygmunta Miłkowskiego z Polonią amerykańską, „Studia Śląskie” 57(1998), s. 155-167.

FlorkowsKa-Frančić H., Polacy w Szwajcarii po powstaniu styczniowym wobec kraju azylu, „Przegląd Polonijny” 1992, z. 3, s. 33-42.

FLORKOWSKA-FrančIĆ H., Uroczystości rapperswilskie 1868-1918, „Rocznik Biblioteki Narodowej" 32(1996), s. 267- 280.

FranČIĆ M., Julian Horain i jego korespondencja ze Stanów Zjednoczonych z lat 18711880, „Przegląd Polonijny” 1986, z. 4, s. 51-75.

Groniowski K., Początki organizacji polonijnych w Stanach Zjednoczonych, „Kwartalnik Historyczny" 88(1981), nr 3, s. 669-689.

Groniowski K., Polonia w Stanach Zjednoczonych u schyłku XIX w. Pozycja społeczna i postawy polityczne, „Przegląd Polonijny” 2(1976), nr 1, s. 5-20.

Groniowski K., Rapperswil jako ośrodek polityczny (1868-1887), „Annales UMCS”, Sectio F. Humaniora 1982, t. 37, s. 393-409.

Historia dyplomacji polskiej, t. III: 1795-1918, red. L. Bazylow [i in.], Warszawa: Wydawnictwo Inne 1982.

Historie Polski w XIX wieku, red. A. Nowak, t. IV, Warszawa: Biały Kruk 2015.

KLeJn Z., Policja pruska wobec Polonii amerykańskiej, „Problemy Polonii Zagranicznej” 3(1963), s. 153-168.

Korwin-Milewski H., Siedemdziesiąt lat wspomnień (1855-1925), Poznań 1930. 
KostoŁowski E., Studia nad kwestią włościańską w latach 1846-1864 ze szczególnym uwzględnieniem literatury politycznej, Lwów 1938.

KozŁowski Cz., Zarys dziejów polskiego ruchu robotniczego do 1948 roku, Warszawa: Książka i Wiedza 1980.

KozŁowski E., Generał Józef Hauke-Bosak 1834-1871, Warszawa: MON 1973.

KRUSzKa W., Historia polska w Ameryce. Początek, wzrost i rozwój dziejowy osad polskich w Północnej Ameryce (w Stanach Zjednoczonych i Kanadzie), t. IV, Milwaukee 1905.

KuBIAK H., Rodowód narodu amerykańskiego, Kraków: Wydawnictwo Literackie 1975.

LeŚNIEwsKi Cz., Gmina w Polsce odrodzonej według projektów Towarzystwa Demokratycznego Polskiego z lat 1840-41, [w:] Studia historyczne ku czci Stanisława Kutrzeby, t. II, Kraków 1938.

Mansfeld B., Rapperswil Władysława Platera, „Więź” 1972, nr 11, s. 130-136.

MiciŃSKA M., Inteligencja na rozdrożach 1864-1918, Warszawa: Neriton 2008.

MurzYnowska K., Henryk Korwin-Kałussowski, (1806-1894), „Problemy Polonii Zagranicznej" 4(1964-65), s. 117-128.

MurZYNOwsKa K., Polska emigracja europejska w latach 1870-1923, [w:] Stan i potrzeby badań nad zbiorowościami polonijnymi, Wrocław: Zakład Narodowy im. Ossolińskich 1976, s. 330-343.

NAImark N.M., The History of the „Proletariat”. The Emergence of Marxism in the Kingdom of Poland, 1870-1887, Boulder 1979.

NowaK J., Od narodu historycznego do wspólnoty etnicznej. Przemiany w polskiej refleksji nad narodem po 1864 roku, ,Teksty Drugie” 6(2014), s. 369-390.

Osada S., Historia Związku Narodowego Polskiego, t. I, Chicago 1905.

Pastuszka S., Karol Lewakowski a Skarb Narodowy, „Roczniki Dziejów Ruchu Ludowego" 1973, nr 15, s. 184-209.

Pienkos D., P.N.A. Centennial History of the Polish National Alliance of the United States of North America, Boulder 1984.

Sobolewski M., Od drugiego Cesarstwa do Piątej Republiki. Z dziejów politycznych Francji 1870-1958, Warszawa: Wiedza Powszechna 1963, s. 122-123.

STASIK F., Polska emigracja zarobkowa w Stanach Zjednoczonych Ameryki 1865-1914, Warszawa: PWN 1985.

Stocka A., Stany Zjednoczone w świetle prasy warszawskiej z lat 1865-1877, Białystok 2013.

ŚLADKOWsKi W., Emigracja polska we Francji 1871-1918, Lublin: Wydawnictwo Lubelskie 1980.

Tyrowicz M., Kałussowski Henryk, [w:] Polski Słownik Biograficzny, t. XI, Wrocław 1964-1965, s. 505-507.

Waldo A., Teofila Samolińska Matka Związku Narodowego Polskiego w Ameryce, Chicago 1980.

WereszycKi H., Koniec sojuszu trzech cesarzy, Warszawa: PWN 2010.

WerEszyCKi H., Międzynarodowe echa jubileuszu Kraszewskiego w 1879 roku, „Dzieje Najnowsze" 1974, z. 3, s. 3-20. 
Wieniec pamiątkowy półwiekowej rocznicy powstania listopadowego obchodzonej 29 listopada 1880 r., red. A. Giller, Rapperswil 1881.

Witkowska A., Wielkie stulecie Polaków, Warszawa 1987.

WoJcIECHOwsKa A., Protokół jako świadectwo komunikacji wspólnotowej w drugiej połowie XIX wieku. Studium genologiczne, Zielona Góra: Oficyna Wydawnicza Uniwersytetu Zielonogórskiego 2012.

ZDRADA J., Zmierzch Czartoryskich, Warszawa: PWN 1969.

WPŁYW POLSKIEJ EMIGRACJI W EUROPIE ZACHODNIEJ

NA ŻYCIE POLITYCZNE POLONII AMERYKAŃSKIEJ

PRZEŁOMU LAT SIEDEMDZIESIĄTYCH I OSIEMDZIESIĄTYCH XIX WIEKU

\section{Streszczenie}

Polska diaspora w Stanach Zjednoczonych Ameryki Północnej w XIX wieku zmieniała się w czasie. Zmianom podlegały również wzajemne kontakty między wychodźstwem polskim w Europie Zachodniej a polską emigracją w USA, inaczej nazywaną Polonią amerykańską. Między latami 30. a 60. XIX wieku relacje obu emigracji były sporadyczne. Wpływały na ten stan rzeczy dwa czynniki: oddalenie geograficzne oraz niewielka liczba polskich emigrantów politycznych w Stanach Zjednoczonych. Ta sytuacja zaczęła się zmieniać pod koniec lat 70., kiedy nastąpił rozwój emigracji zarobkowej, który spowodował gwałtowny wzrost ludności polskiego pochodzenia w Ameryce.

W tym okresie przedstawiciele emigracji polskiej w Europie (mieszkający głównie we Francji i Szwajcarii) zaczęli szukać porozumienia ze swoimi odpowiednikami po drugiej stronie oceanu. Robili to na tyle skutecznie, że udało im się doprowadzić do kilku wspólnych inicjatyw. Jedną z nich było powołanie do istnienia Związku Narodowego Polskiego. Niniejszy artykuł stanowi próbę prześledzenia owoców współpracy między wychodźstwem europejskim a amerykańskim na przełomie lat 70. i 80. XIX wieku. Mowa w nim o ludziach oraz instytucjach, które uczestniczyły w tych kontaktach, o sukcesach i porażkach wspólnych inicjatyw.

Słowa kluczowe: Polonia amerykańska; Polonia francuska; Polonia szwajcarska; Związek Narodowy Polski

\section{THE INFLUENCE OF POLISH EMIGRATION IN WESTERN EUROPE IN THE POLITICAL LIFE OF AMERICAN POLONIA AT THE TURN OF THE 1870S AND 1880S}

\section{Sum mary}

The Polish diaspora in the United States of America in the nineteenth century changed over time. Mutual contacts between Polish emigration in Western Europe and Polish emigration in the 
US, also known as the American Polonia, were subject to change. Between the 1830s and 1860s, the relations of both emigrant groups were sporadic. Two factors influenced this state of affairs: their geographical distance and the small number of Polish political emigrants in the United States. This situation began to change in the late 1870s, when economic emigration began to develop, which caused a rapid increase in the Polish origin population in America.

During this period, representatives of the Polish emigration in Europe (mainly living in France and Switzerland) began to seek contacts with their counterparts on the other side of the ocean. They did this so effectively that it lead to several joint initiatives. One of them was the establishment of the Polish National Union. This article is an attempt to trace the fruits of cooperation between the European and American emigration at the turn of the 1870s and 1880s. It talks about the people and institutions that participated in these contacts, including the successes and failures of joint initiatives.

Key words: American Polonia; French Polonia; Swiss Polonia; Polish National Union

Translated by Jan Kobytecki 